\title{
Polish Peasant Party PSL Piast against the Polish reconstruction of Central and Eastern Europe after WWI
}

\section{Introduction}

Political parties are entities which shape the political thought by expressing it formally in their programmes. Aside from the content-related and territorial dimension presented in this article, there is also a temporal aspect, i.e., the $20^{\text {th }}$ century, which was unique for the history of Central and Eastern Europe. The majority of nations inhabiting this part of the continent entered the $20^{\text {th }}$ century without sovereign states of their own. The second half of the $19^{\text {th }}$ century saw modern political movements - national-democratic, socialist and peasant ones - in the Polish lands under partitions propagating the idea of independence and defining their attitude towards other countries, future neighbours of independent Poland. ${ }^{1}$ The author of this article focuses primarily on the projects in the political thought of PSL Piast that referred to the Polish state and its role among the countries of Central and Eastern Europe formed as a result of "the Great War".

PSL Piast (1913/14-1931) was created in the Austrian partition. It played a crucial role in the history of the peasant movement and affected the shape of the reborn Poland. Despite internal heterogeneity, Galician peasant movement activists were permanent members of political life. The peasant movement which originated in Galicia (Zwiazzek Stronnictwa Chłopskiego [The Union of Polish Party] in 1893 and Stronnictwo Ludowe [abbreviated to SL, Peasants Party] in 1895 which was transformed into Polskie Stronnictwo Ludowe [abbreviated to PSL, Polish Peasant Party] in 1903, in December 1913 PSL Piast formed as a result of a split in PSL) wielded a significant political in-

J. Jachymek, Niezwykly stopień komplikacji problematyki zagranicznej w polskiej myśli politycznej XX wieku. Przedmowa [A high degree of complications in foreign affairs in the Polish political thought of the 20th century. Preface.], [in:] Świat wokót Rzeczypospolitej. Problematyka zagraniczna w polskiej myśli politycznej w pierwszej połowie XX wieku [The world around the Republic of Poland. International issues in the Polish political thought of the first half of the 20th century], ed. W. Paruch, K. Trembecka, Lublin 2007, pp. 17-18. 
fluence in the autonomous institutions of Galicia as well as in the Austrian Council of State in Vienna at the beginning of the $20^{\text {th }}$ century. The outbreak of WWI blocked many processes that were underway in the Austro-Hungarian monarchy. ${ }^{2}$

\section{As part of the monarchy}

At the turn of the $20^{\text {th }}$ century, inhabitants of great powers comprised $85 \%$ of the population in Europe. In each of them a substantial part of society did not identify itself with the ruling party. This period was characterised by a rising interest in national issues. New generations stepping onto the political stage contributed to this feeling with their national aspirations. It was particularly noticeable in the territory of Central and Eastern Europe divided between Russia, Germany and Austria-Hungary. ${ }^{3}$

During the time of PSL Piast's activity, numerous transformations in political, social and economic sphere took place in the Polish lands and in Europe, which in turn impacted the content of PSL's ideological concepts. The reality surrounding the party was an important factor that generated sources for the political thought of PSL Piast. Under these changing political and social conditions, the party endeavoured to seek solutions to fundamental problems that concerned the issues of Galicia and also those of independent Poland and Europe.

There are three distinct stages in the history of the party that determine the ideological dimension of its founders. The first one fell on the years 1913-1918. In that time, social aspects merged with the national ones. World War One was the time when PSL Piast either undertook many initiatives on its own or supported others aimed at

2 The Austrian Monarchy transformed into the Austro-Hungarian Empire in 1867. It evolved from an absolutist to a constitutional state. For Poles, the most important part in its constitution was point 3. It postulated the extension of rights for Sejm Krajowy [The Diet of the Kingdom of Galicia and Lodomeria] regarding the right to organize administrative and judicial authorities, codify the penal law and bill of exchange law, and the right to own a separate national fund. On 4 June 1869, Polish became the official language of administrative and judicial authorities. Cf. W. Łazuga, Kalkulować... Polacy na szczytach C.K. Monarchii [Calculating ... Poles at the height of the Imperial-Royal Monarchy], Poznań 2013, pp. 31, 89, 92.

3 W. Łysek, Prometeizm: „imperializm słabości” czy strategia obronna państwa „między Niemcami a Rosja" [Prometeism:'imperialism of weakness' or the defence strategy of the state 'between Germany and Russia'], [in:] Sen o potędze: Bezpieczeństwo, suwerenność, mocarstwowość. Rzeczpospolita Polska 1918-1939 [A dream about power. Security, sovereignty, imperisalism. The Republic of Poland 1918-1939.], ed. E. Maj, et al., Lublin 2014, p. 97; S. Paczos, Refleksje na temat narodu i państwa $w$ polskiej myśli politycznej [Reflections on the Polish nation and state in the Polish political thought], Historia Slavorum Occidentis 2014, issue no. 2 (7), p. 87, bazhum.muzhp.pl, (accessed on 15 March 2019);. Granica między Europą Środkową i Wschodnią a resztą Europy nie jest ostra, a opinie co do jej przebiegu są dyskusyjne [The border between Central and Eastern Europe and the rest of Europe is not clear and the opinions as to its course are controversial]. Cf. W. Paruch, J. Chmura, Kiedy etnos stał się demosem: uwarunkowania historyczne głównego podziału socjopolitycznego w państwach postjugosłowiańskich [When Ethnos became Demos: historical background of the main sociopolitical division in the post-Yugoslavian countries], [in:] Systemy polityczne państw bałkańskich [Political systems of the Balkan States], ed. T. Bichta, M. Podolak, Lublin 2012, pp. 11-16. 
reconstructing the Polish state. The political thought of the party at the end of the partition period concerned mainly the defence and development of national life as well as fighting for independence. In fact, the independence issue constituted the core around which all other problems were taking shape and to which they were also secondary. PSL Piast activists' struggle for independence came into prominence most distinctly in the resolution of 28 May 1917 issued by a deputy Włodzimierz Tetmajer, which stated that the solution to the Polish problem would be to form an independent Polish state consisting of all the Polish lands with the access to the sea. The second period in the history of the party was in the years 1918-1926. Upon regaining the independence, the political thought of PSL Piast was centred around the problems of a state - reviving the independent Republic of Poland after the years of bondage. The last stage was initiated by the May Coup in 1926 and finalized by the unification of all the peasant parties in March $1931 .^{4}$

PSL Piast took over the ideology from its forerunners from the turn of the $20^{\text {th }}$ century, when the ideological-political framework of the peasant movement was developed in Galicia. The ideological and organizational roots of the party had their origin in the output of PSL. Its standard of performance was set by the PSL programme of 1903. What PSL Piast members adopted from that programme was the main political goal, "a reconstruction of independent and united Poland." Given the gradual democratization of monarchy, the programme was feasible in a foreseeable future. It also placed an emphasis on "[...] making Galicia independent together with the Grand Duchy of Cracow and the Polish part of Silesia to such an extent that was granted to the Kingdom of Hungary in 1867."' A more expressive nature than that of the PSL declarations of 1903 was the standpoint of PSL Piast presented in the Congress resolutions by Wincenty Witos, adopted at the $1^{\text {st }}$ Peasant Movement Congress on 1-2 February 1914 in Tarnów. Witos underlined that "the right of the Polish nation to build an independent People's Poland should be a starting point and the centre of all aspirations and work of the Polish people organized around PSL." On 2 March 1914 in Sejm Krajowy [the Sejm of the Land], he declared that "Peasant Party based on its programme shall strive to create an

4 M. Wichmanowski, Myśl polityczna Polskiego Stronnictwa Ludowego Piast 1913/14-1931 [The political thought of the Polish Peasant Party Piast 1913-1931], Lublin 2017, pp. 45-46.

5 Program Polskiego Stronnictwa Ludowego - 27 luty 1903, Rzeszów [The programme of the Polish Peasant Party], [in:] S. Lato, W. Stankiewicz, Programy stronnictw ludowych - zbiór dokumentów [The programmes of peasant parties - selection of documents], Warsaw 1969, pp. 75-76. Having concluded an agreement with Hungary in 1867, the Habsburg monarchy was transformed into two separate states, Austria-Hungary was formed which was unified by a personal union. They were joined by the person of a monarch who held the title of the emperor (Cisleithania) in Austria and in Hungary the title of a king (Transleithania). To extend the autonomy and to make it equal to the rights enjoyed by Austria and Hungary, to create a modern federal monarchy - these were the plans of all the nations living under the rule of the Habsburg monarchy at the time of the Partitions when thinking about independence was still unrealistic. Cf. A. Indraszczyk, Polski ruch ludowy wobec integracji europejskiej [Polish peasant movement towards European integration], Warsaw 2014, p. 63 . 
independent People's Poland at any cost, as its ideal [...] however distant it may be, but [...] it is indestructible."

Habsburg Monarchy comprised 11 nations and 17 crown states. It possessed 20 legislative bodies, 27 parties and "a countless number of worldviews". In Austria-Hungary, the loyalist stance towards the House of Habsburg was dominating. Political debates on the shape of the public life in the Habsurg monarchy took place before the parliament in Budapest and Vienna or in the so-called "landtags"?

The distinguishing feature of Cisleithania (Austria) was the lack of a nation. There was no Austrian nation at that time. German-speaking inhabitants identified themselves and were identified as Germans. They constituted not more than one-third of the Austrian population. Meanwhile, $60 \%$ of the population was composed of Slavic nations. The dominance of Germans, the economically strongest national group, was felt to a different degree by the nations of Cisleithania. Germans were entangled in disputes mainly with Czechs and Slovenes. ${ }^{8}$ At the State Council in Vienna, PSL Piast politicians expressed their positive attitude towards the activists of the so-called "Slavic Union" - an agreement of Czech, Slovenian and Croatian parties fighting for the rights of Slovenes in the state. In the Austrian parliament, they supported the actions of the Union aimed at ensuring defence against Germans. Along with the Democrats they took up cooperation with the representatives of Czechs, Southern Slovenes, with a view to building anti-German front. Among other things, they participated in the great convent of Slavic nations' representatives organized by Czechs in Prague on 13-17 May

6 Archiwum Zakładu Historii Ruchu Ludowego w Warszawie [referred to as: AZHRL] [Archive of the Peasant Movement History Department], Zespół PSL Piast [PSL Piast Team] 1914-1931, file no. 3, Kongresy PSL Piast, sprawozdania, rezolucje, przemówienia, wnioski, uchwały, ulotki [Congresses of PSL Piast, reports, resolutions, speeches, acts, motions and leaflets], 1914, 1921, 1925-1927-1930, 1st Congress of PSL Piast, 1 February 1914, speech made by W. Witos and J. Dąbski, pp. 1-10, (typescript, print); Rezolucja W. Witosa i J. Dąbskiego, uchwalone na Kongresie PSL (późniejsze PSL Piast) w sprawie programu i taktyki wyborczej, [Resolution made by W. Witos and J. Dąbski adopted at PSL Congress (subsequently PSL Piast) on the programme and electoral tactics] Tarnów 1 February 1914, [in:] Materiały źródłowe do historii polskiego ruchu ludowego [Source materials related to the history of the Polish peasant movement], vol. 1: 1864-1918, compiled and edited by K. Dunin-Wąsowicz et al., Warsaw 1966, p. 148; W. Witos, W debacie nad budżetem na rok 1914 [The debate over the budget for the year 1914], 2 III 1914, [in:] Działa wybrane, Dzieła wybrane [Selected Works], vol. 5: Przemówienia [Speeches], ed. J. R. Szaflik, Warsaw 2007, p. 85.

7 W. Paruch, Polityka zdeterminowana przez historię w regionie bałkańskim: anarchia i koncentracja, kontynuacja i destabilizacja [Politics determined by history in the Balcan region: anarchy and concentration, continuation and destablisation], [in:] Wprowadzenie do studiów wschodnioeuropejskich [Introduction of Eastern European studies], vol. 1, Bałkany: przeszłość - teraźniejszość - przyszłość [The Balcans: past-present-future], ed. M. Podolak, Lublin 2013, pp. 77-145.

8 M. Waldenberg, Kwestie narodowe w Europie Środkowo-Wschodniej. Dzieje, idee [The national issues in Central and Eastern Europe. History and ideas.], Warsaw 1992, p. 53. Slovenes were a small nation inhabiting mainly Cisleithania. Upon the end of WWI, they joined the Kingdom of Serbs, Croatians and Slovenes established on 1 December 1918, which in 1929 was transformed into the Kingdom of Yugoslavia. 
1918. ${ }^{9}$ The integration of Slavic nations was viewed by the PSL Piast ideologists in the light of regaining independence.

A prevalent language spoken in the monarchy was German, which, on the other hand, never became an official one in Austria-Hungary. In the Prussian and Russian partitions, the competence in Prussian and Russian languages was required. In the Habsburg monarchy such a requirement was not set.

Against the backdrop of democratizing Austro-Hungarian monarchy, the Polish political theory of some tendencies was taking its shape, new political programmes started to appear, and some leaders came into the picture. Poles were building some kind of alternative patriotism under their own state conditions. They were growing accustomed to their invader by making political careers and taking advantage of the institutions in the liberalizing state of the Habsburg. ${ }^{10}$

Poles stood out among other nations of the monarchy owing to their pragmatism and discipline. Their actions were accompanied by the conviction that there was another political dimension outside the Galician one. Apart from short-term goals, there were also historical reasons that were cited to justify a poor interest in state's affairs as well as egoism or even some kind of machiavellism in the current politics. ${ }^{11}$ Oftentimes PSL Piast politicians emphasized the fact that the Polish issue could not be viewed separately from the context of Europe-wide politics. They argued that the fate of the Polish nation was determined not only on the negotiations with the Habsburg monarchy but also on Vienna, Petersburg and the rest of Europe.

The intensification of propaganda activities aimed at regaining independence in Central and Eastern Europe took place in the period preceding the outbreak of WWI. PSL Piast activists assumed that there was a need for a collaboration programme between the nations if a course of international events happened to work to their disadvantage. During the Great War, a hope appeared together with a chance of embracing independence. They attempted to make use of it first in the context of Russia's downfall and a ferment which ensued there and next after the defeat of central countries and their dissolution on the western front. ${ }^{12}$

In the wake of WWI three multinational powers collapsed, allowing the nations inhabiting their territories to strive for independence. ${ }^{13}$ The abolition of the monarchy liberated numerous nations which had been kept within the state boundaries for centuries. According to the last census conducted before the war (1910) 12 nations constituted the Austro-Hungarian Empire. Hungarians made up approx. 20\% of the population of the whole state and $48 \%$ of the inhabitants of Transleithania (the Kingdom of Hungary). Strongly heterogeneous Slavs constituted together $46 \%$ of the population, $13 \%$

9 Borkowski J., Witos a Polska [Witos and Poland], Chicago 1992, p. 66.

10 W. Łazuga, Kalkulować [Calculating...] ..., p. 9

11 Ibid., pp. 395-396.

12 W. Łysek, Prometeizm...[Prometeism...], p. 98.

13 Ibid., p. 111. 
of which were Czechs, $10 \%$ - Poles, $8 \%$ - Ruthenians (later referred to as Ukrainians), $5 \%$ - Croatians, $4 \%$ Slovaks, $3 \%$ - Serbs, $2 \%$ - Slovenes and 1\% - Muslim Bosnian. Romanians and Italians constituted $6 \%$ and $2 \%$, respectively. ${ }^{14}$ Based on the census of 1897 in the Tsarist Russia there was $43 \%$ of Russians and the remaining $57 \%$ was made up by various nationalities ranging from Lutheran Swedes and Germans, through Orthodox Latvians, Belarusians and Ukrainians, Polish Catholics, Ukrainians Uniates to Shiite Muslims, Sunni Muslims, Kurds and numerous variations of Buddhism believers and others. The Hohenzollern lands were by and large mono-ethnic and unilingual; however, this area was also inhabited by some ethnic minorities such as Poles, Danes, Alsatians and French. ${ }^{15}$

\section{Independent national states in Central and Eastern Europe}

The demise of central powers and the revolution in Russia posed an opportunity to create new states in Europe. Apart from Poles, Czechs, Slovaks and Slovenes, also Ukrainians from Eastern Galicia were preparing to establish their own country. There was already Grand Duchy of Lithuania formed as part of Mitteleuropa in 1918 by the emperor Wilhelm II. Belarusians also made an attempt to create their own country. On 15 October 1918, Poles announced that "they consider themselves [...] to be citizens of a free, united and independent Polish state". On 18 October, Czech countries separated from Austria, on 19 October - southern Slavs, on 20 October - Hungarians, on 21 October - a national assembly of German-Austria was convened in Vienna. Czechs and Slovaks declared their manifesto of independence and Tomas Masaryk came up with an idea of democratic Central Europe. Estonia, Lithuania, Latvia, Romania and Finland - these countries became independent as a result of peace treaties signed by Soviet Russia in $1920 .^{16}$

The tradition of the former Republic of Poland was continuously present in the Polish consciousness. In the $19^{\text {th }}$ century, the state community fell apart breaking ties with neighbouring nations. When in the $20^{\text {th }}$ century historical paths of the Polish nation got separated from adjacent countries, Poland as the reviving state was of a secondary importance. At the time of creating the Polish state, the fights over borders broke out at the frontiers with all the neighbours. ${ }^{17}$

14 J. Forst-Battaglia, Narodowość i język w monarchii austro-wegierskie [Nationality and language in the Austro-Hungarian Monarchy], „Wschód Europy - Восток Европы - East of Europe” 2017, vol. 3, 2, p. 169.

15 P. Johnson, Historia świata od roku 1917 do lat 90-tych [The World history from 1917 to the 90s], London 1992, p. 30.

16 W. Łazuga, Kalkulować...[Calculating...], p. 391.

17 Ed., Budowa przyszłości [Building the future], „Piast”, 26 IX 1920, no. 39, p. 2; M. Wrzosek, Wojny o granice Polski Odrodzonej 1918-1921 [Wars over the borders of a Reborn Poland 1918-1921], Warsaw 1992, passim. 
Regarding the eastern borders of Poland, two programmes were competing for attention of Poles, namely, the federalist programme and the incorporation programme. The former was associated with the group led by Józef Piłsudski. The aim of the federation in the east was to weaken Soviet Russia and isolate it from Poland by countries federalized with Poland (Lithuania, Belarus, Ukraine). The incorporation programme was represented by National Democrats which postulated the inclusion of eastern lands into the Polish state up to the line along the border of the Second Partition, with certain amendments. PSL Piast represented a complex position caused by the lack of its own developed concept. ${ }^{18}$ It was Witos who specified the idea of PSL Piast on 22 February 1919, delivering a speech on behalf of the party in Sejm Ustawodawczy [the Legislative Sejm]. In his declaration, he emphasized the necessity to incorporate all the Polish lands and define the role of the Republic of Poland in the international politics. ${ }^{19}$

In the wake of WWI, a direct influence on the situation in Central and Eastern Europe was gained by France, Great Britain, the United States of America and Italy. These countries were not familiar with the affairs in this part of the continent due to their interest lying elsewhere. Soon it turned out it did not bode well for the newly formed countries, including Poland. ${ }^{20}$ PSL Piast leader believed that a bridging position of Poland between the Baltic Sea and the Black See was of a key significance for the stability of Central and Eastern Europe. Therefore, they claimed that a strategic task of the Polish state was to enter into treaties of alliance with the countries situated in this area as well as to develop such foreign policy which would endeavour to establish long-lasting alliances and to position Poland in an effective system of collective security.

After World War One, Poles did not decide independently on the territorial shape or the borders of the state. As one of the entities developing the political thought in the field of international policy, PSL Piast expressed this formally in subsequent programmes of the party. The values in question were defined by factors affecting the international status of the state: relations with neighbouring countries, bilateral and multilateral alliances, system of collective security and a geopolitical position of Poland, its economic, demographic and military potential, and internal coherence of the society. The political thought of PSL Piast regarding Polish foreign politics was specified in the subsequent programmes of the parties of $1919,1929,1921$ and $1926 .{ }^{21}$ A declaration

18 W. Witos, Moje wspomnienia, t. 2 [My memories, vol. 2], Paris 1964, pp. 255-256.

19 Idem, Ludowcy i chłopi wobec odzyskanej niepodległości [Peasant movement activists and peasants towards regained independence], 22 II 1919 r., [in:] idem, Wybrane dzieła [Selected Works], vol. 5..., p. 110.

20 M. Białokur, Myśl polityczna Joachima Bartoszewicza na tle koncepcji narodowych demokratów w kwestii międzynarodowych gwarancji bezpieczeństwa Drugiej Rzeczypospolitej [Joachim Bartoszewicz political thought against the background of national concepts of democrats regarding international security guarantees for the Second Republic of Poland], [in:] Świat wokół... [The World around...], p. 348.

21 Pakt Ligi Narodów, Wersal 28 czerwiec 1919 [ [Covenant of the League of Nations. Versailles 28 June 2019], [in:] Prawo międzynarodowe i historia dyplomatyczna. Wybór dokumentów [International 
on international policy was also included in the "programme of the state's recovery" developed by the party in December 1922. Based on the arrangements made, the party underlined the necessity of Poland's partnerships and alliances with other countries and in general, peaceful policy. ${ }^{22}$

Having regained independence, finalized the process of shaping the territory and made the ultimate decision on the borders of the Republic of Poland in 1923 by the Conference of Ambassadors, the main goal of Poland's foreign politics became the defence of its newly gained status quo and consistent strengthening of its position in the international arena. The standpoint of PSL Piast on concluded alliances, national security, relations with neighbouring countries and the issue of borders resulted from the assessment of Poland's position in the international environment. The party strongly opted for building cooperation and establishing friendly relations with Poland's neighbours in spite of territorial disputes in the period of shaping its borders.

PSL Piast politicians believed that Poland should create the politics of Central and Eastern Europe and normalize the relations between the countries in this region. They supported the concept of creating a network of alliances between the countries situated in the area of the so-called Intermarium, which would allow for the neutralization of risk posed by the Soviet Russian (later The Union of Socialist Soviet Republics) and Germany. ${ }^{23}$

law and diplomatic history. The seclection of documents.], vol. 2, ed. L. Gelberg, Warsaw 1958, pp. 30-40; Program Polskiego Stronnictwa Ludowego Piast, Warszawa - 29 czerwiec 1919 [Programme of the Polish Peasant Part Piast, Warszawa, 29 June 1919], [in:] S. Lato, W. Stankiewicz, Programy stronnictw..., [Programmes of the peasant parties ...] pp. 164-167; Program Polskiego Stronnictwa Ludowego Piast - 15 luty 19201919 [Programme of the Polish Peasant Party Piast, Warszawa, 15 February 1920], [in:] S. Lato, W. Stankiewicz, Programy stronnictw... [Programmes of the peasant parties...], pp. 177-181; Program Polskiego Stronnictwa Ludowego Piast, Warszawa - 20 listopad 1921 [Programme of the Polish Peasant Part Piast, Warszawa, 20 November 1921], [in:] S. Lato, W. Stankiewicz, Programy stronnictw... [Programmes of the peasant parties...], pp. 195-208; Program Polskiego Stronnictwa Ludowego Piast - 29 listopad 1926, 1919 [Programme of the Polish Peasant Party Piast, 29 November 1926], Kraków, [in:] S. Lato, W. Stankiewicz, Programy stronnictw... [Programmes of the peasant parties...], pp. 255-281.

22 AZHRL, PSL Piast 1914-1931, ref. no. 4, Działalność Rady Naczelnej i Zarządu Głównego PSL Piast, Uchwały, rezolucje, sprawozdania, korespondencja, maszynopis, fotokopie, Obrady Rady Naczelnej, grudzień 1922 - Deklaracja uchwalona na posiedzeniu Rady Naczelnej w sprawie polityki międzynarodowej, kartki bez paginacji [The activity of Supreme Council and the Management Board of PSL Piast, acts, resolutions, reports, correspondence, typescripts, photocopies, the sittings of Supreme Council, December 1922, Declaration adopted at the sitting of Supreme Council on international politics, pages without pagination]; Program Polskiego Stronnictwa... 1920 [Programme of the Polish Peasant Party], [in:] S. Lato, W. Stankiewicz, Programy stronnictw... [Programmes of the peasant parties ...], p. 177; Program Polskiego Stronnictwa... [Programme of the Polish Peasant Party ...] 1921, [in:] S. Lato, W. Stankiewicz, Programy stronnictw... [Programmes of the peasant parties ...], p. 199; ed., Podstawa uzdrowienia stosunków, „Piast” [Attempt to revive relations, Piast], 7 I 1923, no. 1, pp. 1-2.

23 Traktat między Głównymi Mocarstwami Sprzymierzonymi i Stowarzyszonymi a Polska, Wersal, 28 czerwca $1919 \mathrm{r}$. [Treaty between great powers allied and associated and Poland, Versaille 28 June 
In the first years of Poland's independence, when the concepts for international politics were being formed, Witos played a crucial role. He stood for the stabilization of the Versailles system which Germany strove to revisit. He also overcame the neighbouring countries' anti-Polish attitudes, Russian and German partitioning embitterment and historical grievances with Czechoslovakia. ${ }^{24}$

\section{PSL Piast towards cooperation and safety in Central and Eastern Europe}

PSL Piast leaders failing to exert any significant influence on the Polish foreign policy, did not develop any consistent and cohesive system of alliances. They considered the agreement concluded on 17 March 1922 between Poland, Finland, Latvia and Estonia creating Baltic Union to be beneficial. The agreement was not ratified by the Finnish parliament as a result of German pressure. ${ }^{25}$ Being aware of Poland's geopolitical position and its necessity to balance between Russia and Germany, they propagated the Central European federation whose political and ideological core was to be composed of peasant parties. This initiative was first put forward by Aleksander Stambolijski, a leader of Bulgarian Peasant Union. He was full of hope observing peasant organizations in the countries of the region: Poland, Czechoslovakia, Kingdom of Serbs, Croatians and Slovenes. In April 1921, PSL Piast congress in Cracow adopted a resolution titled "PSL Congress [...] recommends that the Presidium of PSL party closely follow the action already taken by peasant organizations in the neighbouring countries aimed at creating an international peasant organization". ${ }^{26}$ International Agrarian Bureau was

1919], [in:] Historia XIX i XX wieku: Źródła do dziejów Polski w XIX i XX wieku, [History of 19th and 20th century: Sources regarding the history of Poland in 19th and 20th century] vol. 3: Lata 1918-1939: Polska niepodległa. Wybór tekstów źródłowych [Years 1918-1939: Independent Poland, Selection of source texts], edited by A. Koseski, J. R. Szaflik, R. Turkowski, Pułtusk 1998, pp. 20-26; W. Witos, Ludowcy i chłopi wobec odzyskanej niepodległości [Peasant movement activists and peasants towards regained independence], 22 II 1919 r., [in:] idem, Dzieła wybrane [Selected works], vol. 5..., p. 110; W. Stankiewicz, Ruch ludowy w pierwszych latach niepodległości (1918-1923) [Peasant movement in the first years of independence], [in:] Zarys historii polskiego ruchu ludowego [The Outline of the history of the Polish peasant movement], vol. 2: 1918-1939, edited by J. Borkowski et al., Warsaw 1970, p. 49.

24 W. Witos, Uwagi do ratyfikacji traktatu pokojowego pomiędzy mocarstwami sprzymierzonymi a Niemcami, 31 VII 1919r [Comments on the ratification of the peace treaty between great powers allied and associated and Germany, 31.07.1919]., [in:] idem, Dzieła wybrane [Selected works], vol. 5..., p. 142

25 A special position among Baltic countries was held by Lithuania, separated from USSR by the socalled Vilnius passage. Lithuanian state had not maintained any diplomatic relations with Poland until 1938. The border between two neighbours was closed. Cf. M. K. Kamiński, M. J. Zacharias, Polityka zagraniczna II Rzeczypospolitej 1918-1939 [Foreign politics of the Second Republic of Poland 1919-1939], Warsaw 1987, pp. 44, 60-61, 79-80; A. Skrzypek, Związek Baltycki: Litwa, Łotwa, Estonia i Finlandia w polityce Polski i ZSRR w latach 1919-1925 [Baltic Union, Lithuania, Latvia, Estonia and Finland in the politics of Poland and the USSR in the years 1919-1925], Warsaw 1972, passim.

26 W. Witos, Rok 1925. Porozumienie z Czechami [The year 1925. Agreement with Czechs], [in:] idem, Dzieła wybrane [Selected works], vol. 3: Moja tułaczka w Czechosłowacji [My wandering in Czechoslovakia], compiled by E. Karczewski, J.R. Szaflik, Warsaw 1995, p. 504; ed., Kongres PSL w Krakowie 
set up in the years 1921-1923. Bulgarians and Czechs were asking for the participation of Poles. The Polish peasant movement was important for ideological reasons. In 1924, Czech agrarian representatives paid a visit to PSL Piast activists. In 1925, PSL party delegates made a return visit in Czechoslovakia. ${ }^{27}$

All the political events, plans, conferences and ideas emerging in Europe, PSL Piast politicians viewed in the context of the national interest. A crucial element of the Polish system of security was to be an alliance with France and Poland's solidarity with the western countries as well as the ones situated in Central and Eastern Europe. During a congress of PSL delegates from Warsaw province on 29 June 1924, Jan Dębski said, "[...] Polish politics was and still is peaceful, [...] it should, however, closely follow the development of political relations in Europe [...]”.28

PSL Piast politicians saw important elements of the European security system in friendly and allied relations with Czechoslovakia. They realised that Czechoslovakia had to be a friendly neighbour due to the threat posed by Germans. At the meeting of Ministers Council on 28 June 1921 Maciej Rataj submitted a motion to authorize the Minister of Foreign Affairs to initiate negotiations with Czechoslovakia regarding the political agreement acknowledging the borders of the Republic of Poland determined in the Riga Treaty by Czechoslovakia and acknowledging the border in Cieszyn Silesia by Poland. In addition, Czechoslovakia was supposed to not interfere in the internal politics of Poland (related to Western Lesser Poland) and Poland in the affairs of Czechoslovakia (Subcarpathian Ruthenia, Slovakia). Rataj also advocated the conclusion of trade and transit agreements between Poland and Czechoslovakia. ${ }^{29}$

As the Prime Minister of Government of National Defence, Witos made an official statement in favour of normalizing relationships with Czechoslovakia and establishing economic cooperation despite his negative judgement of Czechoslovakia's actions during the fights over the borders. ${ }^{30}$ In subsequent years, PSL Piast members became

[PSL Congress in Cracow], „Piast”, 10 IV 1921, no. 15, p. 5; ed., Agrarny Związek Ludowy w Bułgarii [Agrarian Peasant Union in Bulgaria], „Piast”, 1 V 1921, no. 18, pp. 6-7; B. Turk, Międzynarodówka Chłopska [The Peasant International], „Piast”, 30 X 1921, no. 44, p. 5.

27 A. Indraszczyk, Zielona Międzynarodówka.. Wspótpraca partii chłopskich i państw Europy Środkowej $i$ Wschodniej [Cooperation of peasant parties and countries of Central and Eastern Europe], Warsaw 2008, pp. 47-56.

28 Zjazd delegatów PSL województwa warszawskiego [Congress of PSL delegates from the Warsaw Province], „Piast”, 13 VII 1924, no. 28, p. 3.

29 A. Kołodziejczyk, Myśl polityczna Macieja Rataja. Studia i szkice [The political thought of Maciej Rataj. Studies and essays], Warsaw 1990, pp. 75-76.

30 W. Witos, O zwycięstwie nad bolszewikami i stanie państwa, 24 IX 1920 [About the victory over Bolsheviks and the condition of the state, 24.09.1920], [in:] Idem, Dzieła wybrane [Selected works], vol. 5..., pp. 183, 184; J. Gnida, Unia polsko-czechosłowacka [Polish-Czechoslovakian Union], „Młoda Myśl Ludowa” [Young Peasant Thought], II 1926, no. 1, pp. 5-6; A. Indraszczyk, Zielona Międzynarodówka... [Green International], passim; Idem, Polski ruch ludowy... [Polish peasant movement...], pp. 102-105; J. Jachymek, Ruch ludowy [Peasant movement], [in:] Więcej niż niepodległość. Polska myśl polityczna 1918-1939 [More than independence. Polish political thought 
the proponents of a rapprochement with Czechoslovakia, from which Poland could derive significant political benefits, whereas Czechoslovakia might profit commercially. ${ }^{31}$

During the second government led by Witos, the role of the Polish ambassador in Prague was served by Zygmunt Lasocki, while Aleksander Skrzyński acted as the minister of foreign affairs. Due to their commitment three agreements were signed between Poland and Czechoslovakia. According to PSL Piast politicians they paved the way for cooperation. After several years, in February 1926 during the meeting of the party's management board, the party's foreign affairs committee was requested to conduct research on the project of a Polish-Czechoslovakian union. PSL Piast was convinced that "the Polish foreign policy should be oriented towards peace reinforcement and political and economic consolidation particularly in this part of Europe which can be affected directly" and furthermore "it should strive to develop existing relationships with its neighbours". The party politicians, in their assumptions, viewed this union as a customs territory which could be joined by Yugoslavia and Romania. The idea of the union was for the states to defend themselves against Germany. Apart from the threat from Germany, PSL Piast also pointed to the Soviet Union as a potential danger. For small countries which emerged as a result of WWI such a union would serve as a support. It could draw these countries together and expand it to all the states situated in Central and Eastern Europe. ${ }^{32}$

As part of the Lanckorona Pact in mid-May 1923, Wincenty Witos and Władysław Kiernik on behalf of PSL Piast signed an agreement in which the party presented its view on the most important problems of foreign policy. It was noted that "foreign policy should be peaceful and aim at strengthening and securing borders as well as the state's influences in international affairs. A particular emphasis was to be placed on economic policy and gaining markets on the West and in the Balkans. In addition, PSL Piast activists found it significant to pay attention to the threat from Germany and to normalize relations with Czechoslovakia, to retain all the rights conferred upon Poland by virtue of the Treaty of Versailles, to sign trade treaties in the West. ${ }^{33}$ In 1923 in his expose in the Sejm Witos declared that "regarding foreign policy the government shall

1918-1939], edited by J. Jachymek, W. Paruch, Lublin 2001, p. 252; P. Matusak, Udział ludowców $w$ polskiej dyplomacji lat międzywojennych i po II wojnie światowej [The involvement of the peasant party activists in the Polish diplomacy in the interwar period and after WWII], [in:] Chłopi, naród, kultura [Peasants, nation and culture], vol. 2: Działalność polityczna ruchu ludowego [Political activity of the peasant movement], ed. S. Dąbrowski, Rzeszów 1996, p. 313.

31 Wiadomości z Polski i ze świata [News from Poland and the World], „Piast”, 19 X 1924, no. 42, p. 8.

32 A. Indraszczyk, Polski ruch ludowy... [Polish peasant movement...], pp. 102-104.

33 Zasady wspótpracy stronnictw polskiej większości parlamentarnej w Sejmie w r. 1923, tak zwany Pakt Lanckoroński, Warszawa 17 maj 1923 [Principles of cooperation between the parties of the Polish parliamentary majority in the Sejm of 1923, the so-called Lanckorona Pact, Warsaw 17 May 1923], [in:] Materiały źródłowe do historii polskiego ruchu ludowego [Source texts regarding the history of the Polish peasant movement], vol. 2: 1918-1931, compiled by. S. Giza, S. Lato, Warsaw 1967, p. 81. 
follow already tested path of peaceful means and cooperation with the neighbours at the same guarding the state's interests and sovereignty". ${ }^{34}$

At the meeting of the Supreme Council of PSL Piast in February 1924 several key resolutions were adopted manifesting the party's attitude towards the foreign policy, namely, "1. The Treaty of Versailles as a foundation of universal peace cannot be revisited. 2. Polish foreign policy characterised by particularly peaceful tendencies, strives to maintain the best relationships with all the states; therefore, Poland supports the ideals of the League of Nations and wishes to cooperate with it in order to consolidate widespread peace. 3. As long as Poland does not have any guarantee of peaceful policy led by its neighbours, it needs to fall back on the system of alliances of a defensive character, developing existing pacts and treaties. 4. Alliances that Poland has concluded do not preclude the possibility of reaching an agreement with a lot of states, in the first place with England and Italy. The idea of these agreements was to guarantee peace and improve economic life in Europe. 5. Raising the issues related to the east in the international politics should contribute to the rise of our country's significance in the international arena. 6. Upon determining peaceful conditions with Russia enforced by the Treaty of Riga, obligations stipulated therein should be closely fulfilled, which may speed up economic closeness between two countries". ${ }^{35}$ The party's political thought expressed in the resolutions of Supreme Council of PSL Piast includes the texts of programmes concerning foreign policy, which were extended and complemented in accordance with the current events. During a congress of PSL Piast in Warsaw on 7-8 December 1924, some crucial aspects of the state's foreign policy were brought up. Jan Dębski emphasized that the state's foreign policy was of a paramount importance for the party leadership and it "[...] must serve the interest of the country".36

The approach of western European powers to Germany deeply disappointed the leadership of the party. Peasant party activists shared a conviction that Germans constituted the enemy number one. Polish-German relations were fraught with tensions due to their past: partitions, germanization as well as the current events and decisions: uprisings, plebiscites, territorial disputes, the provisions of the Treaty of Versailles, a dispute over Polish mail boxes in the Free City of Danzig in 1925, the case of Optanten, and a customs war against Poland waged by Germans in 1925. PSL Piast leaders were of an opinion that a basis for the German policy was to abolish the provisions of the Treaty of Versailles. According to peasant movement politicians Russia was the enemy number two for Poland. Polish-Russian relations were also burdened with historical circumstances such as: partitions, brutally crushed national-liberation uprisings, the policy of russification of Poland, Bolshevik revolution, systemic differences, a war im-

34 W. Witos, Expose prezesa Rady Ministrów, 1 czerwca 1923 r. [Expose of the Prime Minister, 1 June 1923], [in:] Idem, Dzieła wybrane [Selected works], vol. 5..., p. 305.

35 Uchwaty Rady Naczelnej PSL [Resolution of the PSL Supreme Council], „Piast”, 17 II 1924, no. 7, p. 6.

36 Red., Sprawozdanie z Kongresu [Report from the Congress], „Piast”, 14 XII 1924, no. 50, p. 5. 
pinging on Poland's sovereignty. When France and England recognized the USSR, PSL politicians pointed to the fact that "it raises concerns over our alliance with them". In order to ensure Poland's security, the idea was to get actively involved in creating pacts of collective security and propagating pacifism. ${ }^{37}$

Recognizing diplomatic demarches in the international politics, the party emphasized the need to support such actions, incorporating the societies of other countries and strengthening a belief in the necessity of peaceful coexistence. On the executive level of the party there was a prevalent conviction that due to the cooperation of peasant parties and democratic European countries it would be realistic to exert pressure on the governments to implement peaceful policy. ${ }^{38}$

37 Traktat wzajemnej gwarancji pomiędzy Belgia, Francją, Wielka Brytania, Włochami i Niemcami, tzw. Pakt Reński, Locarno 16 października 1925 r. [Treaty of mutual guarantees between Belgium, France, Great Britain, Italy and Germany, so-called Lanckorona Pact, Locarno 16 October 1925], „Zbiór Dokumentów" [Collection of documents], 1934, no. 3, p. 60-67; L. Mularska-Andziak, Historia powszechna 1919-1991 [World history 1919-1991]. Wybór tekstów źródłowych [Selection of source texts], Pułtusk 1997, pp. 47-49; M. Rataj, Pamiętniki 1918-1927 [1918-1927 Diaries], compiled by J. Dębski, Warsaw 1965, p. 339; T. Dubicki, G. Łukowski, E. Ponczek, Myśl polityczna i propaganda. Świadomość i cele polskich zmagań w latach 1919-1945 [Political thought and propaganda. Awareness and goals of Polish struggles in the years 1919-1945], Częstochowa 2004, p. 38; ed., O obrone państwa. Mowa posła Dubiela na plenum Sejmu dnia 28 stycznia 1924 [For the defence of the state. A speech made by the deputy Dubiel in the Sejm on 28 January 1924], „Piast”, 4 II 1924, no. 5, pp. 5-7; ed., Wśród wzburzonych fal [Among the raging waves], „Piast”, 29 VI 1924, no. 26, pp. 1-2; Traktat o wyrzeczeniu się wojny, tzw. Pakt Brianda-Kellogga, Paryż 27 sierpnia 1928 [ [Treatise on renouncing the war, so-called Briand-Kellog Pact, Paris 27 August 1928]., Dz. U. [Journal of Laws] RP, 1929, no. 63, item 489; Protokól podpisany w Moskwie, dnia 9 lutego 1929 r. pomiędzy Estonją, Łotwą, Polską, Rumunją i Związkiem Socjalistycznych Republik Rad, dotyczący wejścia w życie Traktatu przeciwwojennego, podpisanego w Paryżu dnia 27 sierpnia 1928 r. (ratyfikowany zgodnie $z$ ustawa $z$ dnia 23 marca 1929 r.) [Protocol signed in Moscow on 9 February 1929 between Estonia, Latvia, Poland, Romania and the USSR concerning the entry of the pre-war treaty signed in Paris on 27 August 1928 into force (ratified in accordance with the act of 23 March 1929)], Dz. U. [Journal of Laws] RP, 1929, no. 29, item 283; ed., Polityka zagraniczna [Foreign policy], „Piast”, 16 XI 1924, no. 46, p. 2; J. Faryś, Koncepcje polskiej polityki zagranicznej 1918-1939 [Concepts of Polish foreign policy], Warsaw 1981, pp. 220-221.

38 Rezolucja Kongresu Obrony Prawa i Wolności Ludu w sprawie zmiany systemu rząów w Polsce, Kraków 29 czerwca $1930 \mathrm{r}$. [The resolution of the congress of people's right and freedom defence on the change of governance system in Poland, Cracow 29 June 1930] [in:] Materiały źródłowe... [Source texts...], vol. 2, p. 372; J. Jachymek, Ruch ludowy [Peasant movement], [in:] Więcej niż... [More than ...], p. 252; Idem, J. R. Szaflik, Myśl polityczna ruchu ludowego wobec bezpieczeństwa granic państwowych w II Rzeczypospolitej [The political thought of the peasant movement towards the security of the state's borders in the Second Republic of Poland], [in:] Polska myśl polityczna XIX iXX wieku [Polish political thought in the 19th and 20th century], vol. 4: Na warsztatach historyków polskiej myśli politycznej [At the workshops of the historians of the Polish political thought], ed. H. Zieliński, Wrocław-Warsaw-Kraków-Gdańsk 1980, p. 231. 


\section{Final remarks}

The underlying cause of the birth of the countries situated in Central and Eastern Europe was a conducive international growth in the years 1917-1918. PSL Piast politicians were seeking an agreement with the neighbouring countries pointing to the possibility of establishing unions with the states formed in Europe in the wake of WWI. The author of an innovative solution was Jerzy Kuncewicz, an outstanding columnist and PSL Piast activist. Referring to a disastrous geopolitical location of Poland, its positioning between two aggressive neighbours, he suggested that new ways and methods should be searched to damp down external hostilities. Analysing the history and the politics conducted by European states at that time, he arrived at the conclusion that integrational and federalist solutions would have to be found in order to ensure peace in Europe.$^{39}$ He proposed the creation of territorial blocks in Europe. He took particular interest in Poland's problems, and in general the ones of Central and Eastern Europe. The blocks in this part of the continent would be formed by the states exposed to the risk of German and Soviet aggression. When the prospect of implementing these plans fell through, PSL Piast leaders in their political programmes limited themselves to their postulates on peaceful international cooperation based on the League of Nations. ${ }^{40}$

PSL Piast politicians in their ideological projections excluded wars from international relations, switching the focus to conciliation when it came to the issues related to nations and states. Poland's position among other countries and nations was dependant on international relations in Europe and in the whole world as well as on the policy of two powerful neighbouring states- Russia and Germany. PSL Piast politicians claimed unfailingly that throughout the whole period of the existence of the Polish statehood, the great powers had a decisive influence both on Poland's history and that of other countries in the region, hence a skill to manage international policy by the government was not without significance. ${ }^{41}$

The location of Polish lands in Europe between the West and the East affected the scenarios concerning political arrangements of subsequent governments, which was most clearly noticeable in the Polish concept of Intermarium. ${ }^{42}$ PSL Piast viewed the Republic of Poland as a state shaping the politics of Central and Eastern Europe, a state

39 Oświadczenie Wincentego Witosa złożone w SU 30 lipca 1920 roku [Declaration of Wincenty Witos made on 30 July 1920], [in:] W. Witos, Dzieła wybrane [Selected works], vol. 2..., pp. 80-81; A. Indraszczyk, Polski ruch ludowy... [Polish peasant movement], pp. 114-115.

40 Ibid, pp. 116-119, 130.

41 M. Rataj, Pamiętniki... [Diaries...] pp. 209-213; M. K. Kamiński, M. J. Zacharias, Polityka zagraniczna... [Foreign policy...], p. 292; J. Karski, Wielkie mocarstwa wobec Polski 1919-1945, Od Wersalu do Jałty, [Great Powers towards Poland 1919-1945: From Versailles to Jalta], Lublin 1998, pp. 9-10, 67-69; J. Jachymek, Sąsiedzi w myśli..., [Neighbours in the thought of...] pp. 242-243.

42 J. Macała, Polska między Wschodem a Zachodem w polskiej geopolityce okresu międzywojennego. Wybrane koncepcje [Poland between the East and the West in the Polish geopolitics of the interwar period. Selected concepts.] [in:] Sen o potędze... [Dreams on power...], p. 35. 
stabilizing relations within this region. According to PSL Piast leaders this activity was determined by independent factors, including geopolitics. The immediate effect of PSL standpoint was the concept of two enemies and neutralization of the threat by creating a network of alliances by the countries situated in the area of so-called Intermarium. ${ }^{43}$

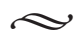

\begin{abstract}
Polish Peasant Party PSL Piast (1913/14-1931) was created in the Polish territory under the Austrian partition. It played a crucial role in the history of the peasant movement and affected the shape of the reborn Poland. The author of this article focuses primarily on the projects in the political thought of PSL Piast that referred to the Polish state and its role among the countries of Central and Eastern Europe formed as a result of "the Great War". PSL Piast politicians were seeking an agreement with the neighbouring countries pointing to the possibility of establishing unions with the states formed in Europe in the wake of WWI. PSL Piast viewed the Republic of Poland as a state shaping the politics of Central and Eastern Europe, a state stabilizing relations within this region. According to PSL Piast leaders this activity was determined by independent factors, including geopolitics. The immediate effect of PSL standpoint was the concept of two enemies and neutralization of the threat by creating a network of alliances by the countries situated in the area of so-called Intermarium.
\end{abstract}

Keywords: peasant movements.

\title{
Polskie Stronnictwo Ludowe Piast wobec rekonstrukcji Europy Środkowej i Wschodniej po I wojnie światowej
}

Streszczenie: Polskie Stronnictwo Ludowe Piast (1913/14-1931) powstało na ziemiach polskich pod zaborem austriackim. Odegrało istotną rolę w dziejach ruchu ludowego i wpłynęło na kształt odrodzonej Polski. Głównym obiektem zainteresowania autora artykułu było wskazanie projektów dotyczących państwa polskiego i jego roli wśród państw Europy Środkowowschodniej powstałych w wyniku „Wielkiej Wojny" w myśli politycznej PSL Piast. Piastowcy poszukiwali porozumienia z narodami ościennymi, wskazując na możliwość tworzenia związków państw powstałych w Europie w wyniku I wojny światowej. W poglądach PSL Piast Rzeczpospolita jawiła się jako państwo kreujące politykę Europy Środkowowschodniej, stabilizujące stosunki tego regionu. Zdaniem liderów PSL Piast, aktywność taką determinowały niezależne czynniki, w tym geopolityka. Bezpośrednim skutkiem stanowiska PSL była koncepcja dwóch wrogów oraz neutralizacja zagrożenia przez utworzenie sieci sojuszy państw położonych na obszarze tzw. Międzymorza.

Słowa kluczowe: Polskie Stronnictwo Ludowe Piast, ruch ludowy.

43 Ibid., pp. 24-25; D. Piotrowski, Rola Leona Wasilewskiego w kształtowaniu i realizowaniu polskiej polityki zagranicznej w okresie budowy II Rzeczypospolitej [The role of Leon Wasilewski in shaping and implementing Polish foreign policy during the construction of the Second Republic of Poland], [in:] Świat wokół... [The world around ...], p. 446. 


\section{Польская народная партия „Пяст" о реконструкции Центральной и Восточной Европы после Первой мировой войны}

Аннотация: Польская народная партия „Пяст” (1913/14-1931) была основана в Польше под «Австрийским Разделом». Она сыграла важную роль в истории народного движения и повлияла на облик возрожденной Польши. Основным объектом интереса автора было обозначение проектов, касающихся польского государства и его роли среди стран Центральной и Восточной Европы, возникших в результате «великой войны» в политической мысли ПНР „Пяст”. Пястовцы добивались соглашений с соседними народами, указывая на возможность формирования ассоциаций государств, образованных в Европе в результате Первой мировой войны. По мнению ПНР „Пяст”, Речь Посполитая предстала как страна, создающая политику Центральной и Восточной Европы, страна, стабилизирующая отношения в этом регионе. По словам лидеров ПНР "Пяст", эта активность определялась независимыми факторами, в том числе геополитическими. Непосредственным эффектом позиции ПНР "Пяст" была концепция двух врагов и нейтрализация угрозы путем создания сети альянсов стран, расположенных в зоне так называемого "Междуморья".

Ключевые слова: Польская народная партия „Пяст", крестьянское движение.

\section{Bibliography}

Archiwum Zakładu Historii Ruchu Ludowego w Warszawie [Archive of the Peasant Movement History Department], Zespół PSL Piast [PSL Piast Team] 1914-1931, file no. 3, Kongresy PSL Piast, sprawozdania, rezolucje, przemówienia, wnioski, uchwały, ulotki [Congresses of PSL Piast, reports, resolutions, speeches, acts, motions and leaflets], 1914, 1921, 1925-1927-1930, 1st Congress of PSL Piast, 1 February 1914, speech made by W. Witos and J. Dąbski, p. 1-10, (typescript, print).

Archiwum Zakładu Historii Ruchu Ludowego w Warszawie [Archive of the Peasant Movement History Department], Zespół PSL Piast [PSL Piast Team] 1914-1931, file no. 4, Działalność Rady Naczelnej i Zarządu Głównego PSL Piast, Uchwały, rezolucje, sprawozdania, korespondencja, maszynopis, fotokopie, Obrady Rady Naczelnej, grudzień 1922 - Deklaracja uchwalona na posiedzeniu Rady Naczelnej w sprawie polityki międzynarodowej, kartki bez paginacji [The activity of Supreme Council and the Management Board of PSL Piast, acts, resolutions, reports, correspondence, typescripts, photocopies, the sittings of Supreme Council, December 1922, Declaration adopted at the sitting of Supreme Council on international politics, pages without pagination].

Białokur M., Myśl polityczna Joachima Bartoszewicza na tle koncepcji narodowych demokratów w kwestii międzynarodowych gwarancji bezpieczeństwa Drugiej Rzeczypospolitej [Joachim Bartoszewicz political thought against the background of national concepts of democrats regarding international security guarantees for the Second Republic of Poland, [in:] Świat wokót Rzeczypospolitej. Problematyka zagraniczna w polskiej myśli politycznej w pierwszej połowie XX wieku [The world around the Republic of Poland. International issues in the Polish political thought of the first half of the 20th century], ed. W. Paruch, K. Trembecka, Lublin 2007.

Borkowski J., Witos a Polska [Witos and Poland], Chicago 1992.

Chłopi, naród, kultura [Peasants, nation and culture], vol. 2: Działalność polityczna ruchu ludowego [Political activity of the peasant movement], ed. S. Dąbrowski, Rzeszów 1996. 
Dubicki T., Łukowski G., Ponczek E., Myśl polityczna i propaganda. Świadomość i cele polskich zmagań w latach 1919-1945 [Political thought and propaganda. Awareness and goals of Polish struggles in the years 1979-1945], Częstochowa 2004.

Dzieła wybrane [Selected works], vol. 5: Przemówienia [Speeches], ed. J. R. Szaflik, Warszawa 2007.

Ed., Agrarny Związek Ludowy w Bułgarii [Agrarian Peasant Union in Bulgaria], „Piast”, 1 V 1921, no. 18, p. 6-7.

Ed., Budowa przyszłości [Building the future], „Piast”, 26 IX 1920, no. 39, p. 2.

Ed., Kongres PSL w Krakowie [PSL Congress in Cracow], „Piast”, 10 IV 1921, no. 15, p. 5.

Ed., 0 obronę państwa. Mowa posła Dubiela na plenum Sejmu dnia 28 stycznia 1924 [For the defence of the state. A speech made by the deputy Dubiel in the Sejm on 28 January 1924], „Piast”, 4 II 1924, no. 5, p. 5-7.

Ed., Podstawa uzdrowienia stosunków, "Piast” [Attempt to revive relations, „Piast”], 7 I 1923, no. 1, p. 1-2.

Ed., Polityka zagraniczna [Foreign policy], „Piast”, 16 XI 1924, no. 46, p. 2.

Ed., Sprawozdanie z Kongresu [Report from the Congress], „Piast”, 14 XII 1924, no. 50, p. 5.

Ed., Wśród wzburzonych fal [Among the raging waves], „Piast”, 29 VI 1924, no. 26, p. 1-2.

Ed., Zjazd delegatów PSL województwa warszawskiego [Congress of PSL delegates from the Warsaw Province], „Piast”, 13 VII 1924, no. 28, p. 3.

Faryś J., Koncepcje polskiej polityki zagranicznej 1918-1939 [Concepts of Polish foreign policy], Warszawa 1981.

Forst-Battaglia J., Narodowość i język w monarchii austro-węgierskie [Nationality and language in the Austro-Hungarian Monarchy], "Wschód Europy - Восток Европы - East of Europe” 2017, vol. 3, 2.

Gnida J., Unia polsko-czechosłowacka [Polish-Czechoslovakian Union], „Młoda Myśl Ludowa” [Young Peasant Thought], II 1926, no. 1, p. 5-6.

Historia XIX i XX wieku: Źródła do dziejów Polski w XIX i XX wieku, [History of 19th and 20th century: Sources regarding thew history of Poland in 19th and 20th century] vol. 3: Lata 1918-1939: Polska niepodległa. Wybór tekstów źródłowych [Years 1918-1939: Independent Poland, Selection of source texts], ed. A. Koseski, J. R. Szaflik, R. Turkowski, Pułtusk 1998.

Indraszczyk A., Polski ruch ludowy wobec integracji europejskiej, [Polish peasant movement towards European integration], Warszawa 2014.

Indraszczyk A., Zielona Międzynarodówka. Współpraca partii chłopskich i państw Europy Środkowej i Wschodniej [Cooperation of peasant parties and countries of Central and Eastern Europe], Warszawa 2008.

Jachymek J., Niezwykły stopień komplikacji problematyki zagranicznej w polskiej myśli politycznej XX wieku. Przedmowa [A high degree of complications in foreign affairs in the Polish political thought of the 20th century. Preface.], [in:] Świat wokół Rzeczypospolitej. Problematyka zagraniczna w polskiej myśli politycznej w pierwszej połowie XX wieku [The world around the Republic of Poland. International issues in the Polish political thought of the first half of the 20th century], ed. W. Paruch, K. Trembecka, Lublin 2007.

Jachymek J., Ruch ludowy [Peasant movement], [in:] Więcej niż niepodległość. Polska myśl polityczna 19181939 [More than independence. Polish political thought 1918-1939], ed. J. Jachymek, W. Paruch, Lublin 2001. 
Jachymek J., Sąsiedzi w myśli politycznej ruchu ludowego (1918-1939) [Neighbours in the political thought of the peasant movement], "Rocznik Nauk Politycznych" ["Political Science Yearbook"] 2002, no 4.

Jachymek J., Szaflik J.R., Myśl polityczna ruchu ludowego wobec bezpieczeństwa granic państwowych w II Rzeczypospolitej [The political thought of the peasant movement towards the security of the state's borders in the Second Republic of Poland], [in:] Polska myśl polityczna XIX i XX wieku [Polish political thought in the 19th and 20th century], vol. 4: Na warsztatach historyków polskiej myśli politycznej [At the workshops of the historians of the Polish political thought], ed. H. Zieliński, Wroctaw -Warszawa-Kraków-Gdańsk 1980.

Johnson P., Historia świata od roku 1917 do lat 90-tych [The World history from 1917 to the 90s], London 1992.

Kamiński M.K., Zacharias M.J., Polityka zagraniczna II Rzeczypospolitej 1918-1939 [Foreign politics of the Second Republic of Poland 1919-1939], Warszawa 1987.

Karski J., Wielkie mocarstwa wobec Polski 1919-1945, Od Wersalu do Jatty, [Great Powers towards Poland 1919-1945: From Versaille to Jalta, Lublin 1998.

Kołodziejczyk A., Myśl polityczna Macieja Rataja. Studia i szkice [The political thought of Maciej Rataj. Studies and essays], Warszawa 1990.

Lato S., Stankiewicz W., Programy stronnictw ludowych - zbiór dokumentów [The programmes of peasant parties - selection of documents], Warszawa 1969.

Łazuga W., Kalkulować... Polacy na szczytach C.K. Monarchii [Calculating... Poles at the height of the Imperial-Royal Monarchy], Poznań 2013.

Łysek W., Prometeizm: "imperializm słabości” czy strategia obronna państwa "między Niemcami a Rosją" [Prometeism:"imperialism of weakness" or the defence strategy of the state "between Germany and Russia"], [in:] Sen o potędze: Bezpieczeństwo, suwerenność, mocarstwowość. Rzeczpospolita polska 1918-1939 [Dream on power. Security, sovereignty, imperisalism. The Republic of Poland 1918-1939], ed. E. Maj, et al., Lublin 2014.

Macała J., Polska między Wschodem a Zachodem w polskiej geopolityce okresu międzywojennego. Wybrane koncepcje [Poland between the East and the West in the Polish geopolitics of the interwar period. Selected concepts] [in:] Sen o potędze: Bezpieczeństwo, suwerenność, mocarstwowość. Rzeczpospolita polska 1918-1939 [Dream on power. Security, sovereignty, imperisalism. The Republic of Poland 1918-1939], ed. E. Maj, et al., Lublin 2014.

Materiały źródłowe do historii polskiego ruchu ludowego [Source materials related to the history of the Polish peasant movement], vol. 1: 1864-1918, compiled and edited by K. Dunin-Wąsowicz et al., Warszawa 1966.

Materiaty źródtowe do historii polskiego ruchu ludowego [Source texts regarding the history of the Polish peasant movement], vol. 2: 1918-1937, compiled by. S. Giza, S. Lato, Warszawa 1967.

Matusak P., Udziat ludowców w polskiej dyplomacji lat międzywojennych i po II wojnie światowej [The involvement of the peasant party activists in the Polish diplomacy in the interwar period and after WWII], [in:] Chłopi, naród, kultura [Peasants, nation and culture], vol. 2: Działalność polityczna ruchu ludowego [Political activity of the peasant movement], ed. S. Dąbrowski, Rzeszów 1996.

Mularska-Andziak L., Historia powszechna 1919-1991 [World history 1919-1991]. Wybór tekstów źródłowych [Selection of source texts], Pułtusk 1997. 
Oświadczenie Wincentego Witosa złożone w SU 30 lipca 1920 roku [Declaration of Wincenty Witos made on 30 July 1920], [in:] idem, Dzieła wybrane [Selected works], vol. 2: Moje wspomnienia [My Memories], part 2, compiled by E. Karczewski, J. R. Szaflik, Warszawa 1990.

Paczos S., Refleksje na temat narodu i państwa w polskiej myśli politycznej [Reflections on the Polish nation and state in the Polish political thought], "Historia Slavorum Occidentis” 2014, no. 2 (7), p. 87 , bazhum.muzhp.pl, (access: 15 III 2019).

Pakt Ligi Narodów, Wersal 28 czerwiec 1919 r [Covenant of the League of Nations. Versailles 28 June 2019], [in:] Prawo międzynarodowe i historia dyplomatyczna. Wybór dokumentów [International law and diplomatic history. The seclection of documents.], vol. 2, ed. L. Gelberg, Warszawa 1958.

Paruch W., Chmura J., Kiedy etnos stał się demosem: uwarunkowania historyczne głównego podziału socjopolitycznego w państwach postjugosłowiańskich [When Ethnos became Demos: historical background of the main sociopolitical division in the post-Yugoslavian countries], [in:] Systemy polityczne państw bałkańskich [Political systems of Balcan states], ed. T. Bichta, M. Podolak, Lublin 2012.

Paruch W., Polityka zdeterminowana przez historię w regionie batkańskim: anarchia i koncentracja, kontynuacja i destabilizacja [Politics determined by history in the Balcan region: anarchy and concentration, continuation and destablisation], [in:] Wprowadzenie do studiów wschodnioeuropejskich [Introduction of Eastern European studies], t. 1, Bałkany: przeszłość - teraźniejszość - przyszłość [The Balcans: past-present-future], ed. M. Podolak, Lublin 2013.

Piotrowski D., Rola Leona Wasilewskiego w kształtowaniu i realizowaniu polskiej polityki zagranicznej w okresie budowy II Rzeczypospolitej [The role of Leon Wasilewski in shaping and implementing Polish foreign policy during the construction of the Second Republic of Poland], [in:] Świat wokół Rzeczypospolitej. Problematyka zagraniczna w polskiej myśli politycznej w pierwszej połowie XX wieku [The world around the Republic of Poland. International issues in the Polish political thought of the first half of the 20th century], ed. W. Paruch, K. Trembecka, Lublin 2007.

Polska myśl polityczna XIX i XX wieku [Polish political thought in the 19th and 20th century], vol. 4: Na warsztatach historyków polskiej myśli politycznej [At the workshops of the historians of the Polish political thought], ed. H. Zieliński, Wrocław - Warszawa - Kraków - Gdańsk 1980.

Prawo międzynarodowe i historia dyplomatyczna. Wybór dokumentów [International law and diplomatic history. The seclection of documents.], vol. 2, ed. L. Gelberg, Warszawa 1958.

Program Polskiego Stronnictwa Ludowego - 27 luty 1903, Rzeszów [The programme of the Polish Peasant Party], [in:] S. Lato, W. Stankiewicz, Programy stronnictw ludowych - zbiór dokumentów [The programmes of peasant parties - selection of documents], Warszawa 1969.

Program Polskiego Stronnictwa Ludowego Piast - 15 luty 19201919 [Programme of the Polish Peasant Party Piast, Warszawa, 15 February 1920], [in:] S. Lato, W. Stankiewicz, Programy stronnictw ludowych - zbiór dokumentów [The programmes of peasant parties - selection of documents], Warszawa 1969.

Program Polskiego Stronnictwa Ludowego Piast - 29 listopad 1926, 1919 [Programme of the Polish Peasant Party Piast, 29 November 1926] Kraków, [in:] S. Lato, W. Stankiewicz, Programy stronnictw ludowych - zbiór dokumentów [The programmes of peasant parties - selection of documents], Warszawa 1969.

Program Polskiego Stronnictwa Ludowego Piast, Warszawa - 20 listopad 1921 [Programme of the Polish Peasant Part Piast, Warszawa, 20 November 1921], [in:] S. Lato, W. Stankiewicz, Programy stronnictw 
ludowych - zbiór dokumentów [The programmes of peasant parties - selection of documents], Warszawa 1969.

Program Polskiego Stronnictwa Ludowego Piast, Warszawa - 29 czerwiec 1919 [Programme of the Polish Peasant Part Piast, Warszawa, 29 June 1919], [in:] S. Lato, W. Stankiewicz, Programy stronnictw ludowych - zbiór dokumentów [The programmes of peasant parties - selection of documents], Warszawa 1969.

Protokół podpisany w Moskwie, dnia 9 lutego 1929 r. pomiędzy Estonją, Łotwą, Polską, Rumunją i Związkiem Socjalistycznych Republik Rad, dotyczący wejścia w życie Traktatu przeciwwojennego, podpisanego w Paryżu dnia 27 sierpnia 1928 r. (ratyfikowany zgodnie z ustawą z dnia 23 marca 1929 r.) [Protocol signed in Moscow on 9 February 1929 between Estonia, Latvia, Poland, Romania and the USSR concerning the entry of the pre-war treaty signed in Paris on 27 August 1928 into force (ratified in accordance with the act of 23 March 1929)], Dz. U. [Journal of Laws] RP, 1929, no. 29, item 283.

Rataj M., Pamiętniki 1918-1927 [Diaries 1918-1927], compiled by J. Dębski, Warszawa 1965.

Rezolucja Kongresu Obrony Prawa i Wolności Ludu w sprawie zmiany systemu rządów w Polsce, Kraków 29 czerwca 1930 r. [The resolution of the congress of people's right and freedom defence on the change of governance system in Poland, Cracow 29 June 1930] [in:] Materiały źródłowe do historii polskiego ruchu ludowego [Source texts regarding the history of the Polish peasant movement], vol. 2: 1918-1931, compiled by. S. Giza, S. Lato, Warszawa 1967.

Rezolucja W. Witosa i J. Dąbskiego, uchwalone na Kongresie PSL (późniejsze PSL Piast) w sprawie programu i taktyki wyborczej, [Resolution made by W. Witos and J. Dąbski adopted at PSL Congress (subsequently PSL Piast) on the programme and electoral tactics] Tarnów 1 February 1914, [in:] Materiały źródłowe do historii polskiego ruchu ludowego [Source materials related to the history of the Polish peasant movement], vol. 1: 1864-1918, compiled and edited by K. Dunin-Wąsowicz et al., Warszawa 1966.

Sen o potędze: Bezpieczeństwo, suwerenność, mocarstwowość. Rzeczpospolita polska 1918-1939 [Dream on power. Security, sovereignty, imperisalism. The Republic of Poland 1918-1939], ed. E. Maj, et al., Lublin 2014.

Skrzypek A., Związek Bałtycki: Litwa, Łotwa, Estonia i Finlandia w polityce Polski i ZSRR w latach 19191925 [Baltic Union, Lithuenia, Latvia, Estonia and Finland in the politics of Poland and the USSR in the years 1919-1925], Warszawa 1972.

Stankiewicz W., Ruch ludowy w pierwszych latach niepodległości (1918-1923) [Peasant movement in the first years of independence], [in:] Zarys historii polskiego ruchu ludowego [The Outline of the history of the Polish peasant movement], vol. 2: 1918-1939, ed. J. Borkowski et al., Warszawa 1970.

Systemy polityczne państw batkańskich [Political systems of Balcan states], ed. T. Bichta, M. Podolak, Lublin 2012.

Świat wokół Rzeczypospolitej. Problematyka zagraniczna w polskiej myśli politycznej w pierwszej połowie XX wieku [The world around the Republic of Poland. International issues in the Polish political thought of the first half of the 20th century], ed. W. Paruch, K. Trembecka, Lublin 2007.

Traktat między Głównymi Mocarstwami Sprzymierzonymi i Stowarzyszonymi a Polską, Wersal, 28 czerwca 1919 r. [Treaty between great powers allied and associated and Poland, Versaille 28 June 1919], [in:] Historia XIX i XX wieku: Źródła do dziejów Polski w XIX i XX wieku, [History of 19th and 20th century: Sources regarding thew history of Poland in 19th and 20th century] vol. 3: Lata 1918-1939: 
Polska niepodległa. Wybór tekstów źródłowych [Years 1918-1939: Independent Poland, Selection of source texts], ed. A. Koseski, J. R. Szaflik, R. Turkowski, Pułtusk 1998.

Traktat o wyrzeczeniu się wojny, tzw. Pakt Brianda-Kellogga, Paryż 27 sierpnia 1928 r. [Treatise on renouncing the war, so-called Briand-Kellog Pact, Paris 27 August 1928]., Dz. U. [Journal of Laws] RP, 1929, no. 63, item 489.

Traktat wzajemnej gwarancji pomiędzy Belgią, Francją, Wielką Brytanią, Włochami i Niemcami, tzw. Pakt Reński, Locarno 16 października 1925 r. [Treaty of mutual guarantees between Belgium, France, Great Britain, Italy and Germany, so-called Lanckorona Pact, Locarno 16 October 1925], „Zbiór Dokumentów" [Collection of documents], 1934, no. 3, p. 60-67.

Turk B., Międzynarodówka Chłopska [The Peasant International], „Piast”, 30 X 1921, no. 44, p. 5. Uchwały Rady Naczelnej PSL [Resolution of PSL Supremen Council], „Piast”, 17 II 1924, no. 7, p. 6.

Waldenberg M., Kwestie narodowe w Europie Środkowo-Wschodniej. Dzieje, idee [The national issues in Central and Eastern Europe. History and ideas.], Warszawa 1992.

Wiadomości z Polski i ze świata [News from Poland and the World], „Piast”, 19 X 1924, no. 42, p. 8.

Wichmanowski M., Myśl polityczna Polskiego Stronnictwa Ludowego Piast 1913/14-1931 [The political thought of the Polish Peasant Party Piast 1913-1937], Lublin 2017.

Więcej niż niepodległość. Polska myśl polityczna 1918-1939 [More than independence. Polish political thought 1918-1939], ed. J. Jachymek, W. Paruch, Lublin 2001.

Witos W., Dzieła wybrane [Selected works], vol. 2: Moje wspomnienia [My Memories], part 2, compiled by E. Karczewski, J. R. Szaflik, Warszawa 1990.

Witos W., Dzieła wybrane [Selected works], vol. 3: Moja tułaczka w Czechosłowacji [My wandering in Czechoslovakia], compiled by E. Karczewski, J.R. Szaflik, Warszawa 1995.

Witos W., Dzieła wybrane [Selected works], vol. 5: Przemówienia [Speeches], ed. J. R. Szaflik, Warszawa 2007.

Witos W., Expose prezesa Rady Ministrów, 1 czerwca 1923 r. [Expose of the Prime Minister, 1 June 1923], [in:] Idem, Dzieła wybrane [Selected works], vol. 5: Przemówienia [Speeches], ed. J. R. Szaflik, Warszawa 2007.

Witos W., Ludowcy i chłopi wobec odzyskanej niepodległości [Peasant movement activists and peasants towards regained independence], 22 I/ 1919 r., [in:] idem, Wybrane dzieła [Selected Works], vol. 5: Przemówienia [Speeches], ed. J. R. Szaflik, Warszawa 2007.

Witos W., Ludowcy i chłopi wobec odzyskanej niepodległości [Peasant movement activists and peasants towards regained independence], 22 /I 1919 r., [in:] idem, Dzieła wybrane [Selected works], vol. 5: Przemówienia [Speeches], ed. J. R. Szaflik, Warszawa 2007.

Witos W., Moje wspomnienia, t. 2 [My memories, vol. 2], Paryż 1964.

Witos W., 0 zwycięstwie nad bolszewikami i stanie państwa, 24 IX 1920 [About the victory over Bolsheviks and the condition of the state, 24.09.1920], [in:] Idem, Dzieła wybrane [Selected works], vol. 5: Przemówienia [Speeches], ed. J. R. Szaflik, Warszawa 2007.

Witos W., Rok 1925. Porozumienie z Czechami [The year 1925. Agreement with Czechs], [in:] idem, Dzieła wybrane [Selected works], vol. 3: Moja tułaczka w Czechosłowacji [My wandering in Czechoslovakia], compiled by E. Karczewski, J.R. Szaflik, Warszawa 1995.

Witos W., Uwagi do ratyfikacji traktatu pokojowego pomiędzy mocarstwami sprzymierzonymi a Niemcami, 31 VII 1919r [Comments on the ratification of the peace treaty between great powers allied and 
Pobrane z czasopisma Wschód Europy http://journals.umcs.pl/we

Data: 26/04/2023 03:23:28

associated and Germany, 37.07.1919], [w:] idem, Dzieła wybrane [Selected works], vol. 5: Przemówienia [Speeches], ed. J. R. Szaflik, Warszawa 2007.

Witos W., W debacie nad budżetem na rok 1914 [The debate over the budget for the year 1974], 2 III 1914,

[w:] Działa wybrane [Selected Works], vol. 5: Przemówienia [Speeches], ed. J. R. Szaflik, Warszawa 2007.

Wprowadzenie do studiów wschodnioeuropejskich [Introduction of Eastern European studies], t. 1, Batkany: przeszłość - teraźniejszość - przyszłość [The Balcans: past-present-future], ed. M. Podolak, Lublin 2013.

Wrzosek M., Wojny o granice Polski Odrodzonej 1918-1921 [Wars over the borders of a Reborn Poland 1918-1921], Warszawa 1992.

Zarys historii polskiego ruchu ludowego [The Outline of the history of the Polish peasant movement], vol. 2: 1918-1939, ed. J. Borkowski et al., Warszawa 1970.

Zasady wspótpracy stronnictw polskiej większości parlamentarnej w Sejmie w r. 1923, tak zwany Pakt Lanckoroński, Warszawa 17 maj 1923 [Principles of cooperation between the parties of the Polish parliamentary majority in the Sejm of 1923, so-called Lanckorona Pact, Warsaw 17 May 1923], [in:] Materiaty źródłowe do historii polskiego ruchu ludowego [Source texts regarding the history of the Polish peasant movement], vol. 2: 1918-1937, compiled by. S. Giza, S. Lato, Warszawa 1967. 